\title{
Removal of $\boldsymbol{N}$-terminal methionine from haemoglobin nascent peptides by a membrane-bound rat liver methionine aminopeptidase
}

\author{
Carlos TERMIGNONI, $\ddagger$ José O. FREITAS, Jr.* and Jorge A. GUIMARÃES $\dagger \S$ \\ *Departamento de Bioquímica, Escola Paulista de Medicina, Rua Botucatu 862, 01000 São Paulo, Brazil, and \\ †Departamento de Bioquímica, Instituto de Ciências Biomédicas, Universidade Federal do Rio de Janeiro, C.P. 68041, \\ 21910 Rio de Janeiro, R.J., Brazil
}

\begin{abstract}
A membrane-bound aminopeptidase able to remove methionine from haemoglobin nascent peptides is described. The enzyme also hydrolyses methionine from methionyl-lysyl-bradykinin but not lysine from lysyl-bradykinin. The tripeptide Met-Ala-Ser is poorly hydrolysed. This aminopeptidase also splits amino acid 2-naphthylamides, being, however, less specific with respect to these synthetic substrates.
\end{abstract}

\section{INTRODUCTION}

Aminopeptidases (EC 3.4.11.-) are enzymes able to hydrolyse the peptide bond of $N$-terminal amino acids in peptides and proteins. These enzymes are also able to split amino acid 2-naphthylamides, the latter hydrolysis usually being named arylamidase activity. Arylaminopeptidases obtained from several sources and showing activity upon $N$-terminal leucine, alanine, arginine (or lysine) and aspartic acid (or glutamic acid) have been reported by several authors (for review see McDonald \& Schwabe, 1977). A role for these enzymes in the catabolism of peptides and proteins is usually suggested, but only a few pieces of evidence for their physiological role in cells have been unequivocally shown. Possible exceptions are the inactivation of oxytocin (Tuppy \& Nesvadba, 1957) and enkephalins (Hambrook et al., 1976), conversion of endorphins (Burch et al., 1980; Hersh et al., 1980), dynorphins (Berg \& Marks, 1984) and the less active peptides methionyl-lysyl-bradykinin and lysyl-bradykinin into the more potent hypotensive nonapeptide bradykinin (Guimarães et al., 1973).

Another function of these enzymes could be related to the presence of an intracellular aminopeptidase, which is suggested to be responsible for the removal of $N$-terminal methionine from nascent peptides during protein synthesis (Yoshida \& Lin, 1972). There are certain cases, however, as happens in the synthesis of human growth hormone by a DNA-recombinant technique, in which the methionine residue remains attached to the $N$-terminal end of the synthesized protein (Olson et al., 1981). Thus clear evidence for the presence of such an enzyme and of its characterization have not been provided so far, although its existence is widely accepted. We have previously shown that rat liver subcellular fractions contain a typical methionine aminopeptidase distinct from previously described arylaminopeptidases (Freitas et al., 1981, 1985). In the present work we have further studied the properties of this aminopeptidase, with special reference to its ability to hydrolyse substrates containing $N$-terminal methionine in amino acid derivatives as well as peptides, including haemoglobin nascent peptides.

\section{MATERIALS AND METHODS}

\section{Rat liver homogenate}

The livers from adult Wistar rats were minced and homogenized in an Ultra-Turrax homogenizer (30 s at $20000 \mathrm{rev}$. $/ \mathrm{min}$ ) with $4 \mathrm{vol}$. of $0.25 \mathrm{M}$-sucrose $/ 10 \mathrm{mM}$ -

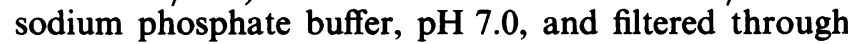
four layers of tissue cloth. All steps were performed at $4^{\circ} \mathrm{C}$. The filtrate was centrifuged at $700 \mathrm{~g}$ for $10 \mathrm{~min}$ to give the crude liver homogenate.

\section{Subcellular fractions}

Subcellular fractionation of rat liver homogenate was performed essentially by the differential centrifugation method (Chambers \& Rickwood, 1978). Subcellular fractions obtained included nuclei $(\mathrm{N})$, heavy mitochondria (M), light mitochondria (L), microsomal fraction (P) and the soluble fraction (S). The integrity of the particles was checked and confirmed by electron microscopy as well as by using the enzyme markers glutamate dehydrogenase, glucose-6-phosphatase and tartrate-inhibitable acid phosphatase.

\section{Enzyme fractionation}

MAP was prepared as described previously (Freitas et al., 1981). Rat liver homogenate or its subcellular organelles were treated with Triton $\mathrm{X}-100$ in a detergent/protein ratio of $5: 1(\mathrm{w} / \mathrm{w})$. The mixture was stirred for $30 \mathrm{~min}$ and centrifuged at $10000 \mathrm{~g}$ for $30 \mathrm{~min}$ to remove debris. The supernatant was precipitated with $\left(\mathrm{NH}_{4}\right)_{2} \mathrm{SO}_{4}(0.35-0.60$ saturation). The pellet obtained after centrifugation was dissolved in and dialysed against $20 \mathrm{~mm}$-sodium phosphate buffer, pH 7.0, containing $0.05 \%(\mathrm{v} / \mathrm{v})$ Triton X-100 and $1.0 \mathrm{~mm}$-2-mercaptoethanol. The clear Triton-solubilized samples were

Abbreviation used: MAP, methionine aminopeptidase.

$\ddagger$ Present address: Faculdade de Veterinaria, Universidade Federal do Rio Grande do Sul, Av. Bento Gonçalves 9090,90000 Porto Alegre, R.S., Brazil.

$\S$ To whom correspondence should be addressed.

Vol. 234 
applied to the DEAE-cellulose columns previously equilibrated with the sample mixture buffer. After the column had been washed with the equilibrating buffer to remove the non-adsorbed protein peak, a linear gradient (20-200 mM-phosphate, $\mathrm{pH} 7.0$ ) was then applied to the column. The active fractions obtained at the non-retained protein peak were combined and concentrated by pressure dialysis and gel-filtered on a $2.6 \mathrm{~cm} \times 92 \mathrm{~cm}$ Bio-Gel A- $0.5 \mathrm{~m}$ column equilibrated and percolated with 20 mM-sodium phosphate buffer, pH 7.0, containing $1.0 \mathrm{~mm}-2$ mercaptoethanol. The active fractions were pooled and used as MAP (Freitas et al., 1985).

\section{Preparation of haemoglobin nascent peptides}

Haemoglobin nascent peptides were prepared from rabbit reticulocytes as described by Yoshida et al. (1970). Reticulocytes were obtained from rabbits made anaemic by phenylhydrazine treatment. The cells were washed with cold saline solution $(140 \mathrm{~mm}-\mathrm{NaCl} / 5 \mathrm{~mm}-\mathrm{KCl} /$ $1.5 \mathrm{mM}-\mathrm{MgCl}_{2}$ ), suspended in $100 \mathrm{ml}$ of this medium containing glucose, salts, labelled methionine $(350 \mu \mathrm{Ci}$ of $\left[{ }^{14} \mathrm{C}\right]-$ or $\left[{ }^{35} \mathrm{~S}\right]-$-methionine) and a mixture of non-radioactive amino acids (Yoshida et al., 1970) and incubated at $37^{\circ} \mathrm{C}$ for $12 \mathrm{~min}$. After incubation the reticulocytes were washed three times with cold saline and then haemolysed in water. The material was centrifuged and the ribosomes were precipitated from the supernatant at pH 5.1. Nascent peptides were dissociated from ribosomes by alkaline treatment $\left(\mathrm{pH} 10.5,30^{\circ} \mathrm{C}, 3 \mathrm{~h}\right)$. Ribosomes

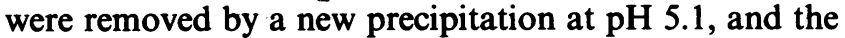
nascent peptides were obtained by freeze-drying the supernatant. Peptides were fractionated on a previously calibrated Sephadex G-25 column $(1.80 \mathrm{~cm} \times 190 \mathrm{~cm})$ developed with $0.5 \%(\mathrm{v} / \mathrm{v})$ formic acid. The fractions corresponding to peptides smaller than glucagon and larger than a single amino acid were pooled, freeze-dried and used as the preparation of haemoglobin nascent peptides. These labelled-methionine-containing peptides were then used for testing MAP peptidase activity.

\section{Assay of enzyme activity}

Hydrolysis of amino acid 2-naphthylamides (e.g. methionine 2-naphthylamide) was monitored by the method of Barrett (1972). Briefly, the incubation mixture $\left(1.5 \mathrm{ml}\right.$ at $\left.37^{\circ} \mathrm{C}\right)$ contained $410 \mathrm{nmol}$ of the $\mathrm{L}$-forms of the amino acid derivatives, 5-100 $\mu 1$ of enzyme samples and $1.0 \mathrm{~mm}-2$-mercaptoethanol in $150 \mathrm{~mm}-\mathrm{NaCl} / 10 \mathrm{~mm}$ sodium phosphate buffer, $\mathrm{pH}$ 7.0. The reaction was interrupted by adding $1.10 \mathrm{ml}$ of a freshly prepared reagent containing a 1:1 mixture of (a) Fast Garnet solution $[0.5 \mathrm{mg} / \mathrm{ml}$ containing $4 \%(\mathrm{v} / \mathrm{v})$ Brij-35] and $(b)$ $10 \mathrm{~mm}$-p-hydroxymercuribenzoate containing $50 \mathrm{~mm}$ EDTA. Hydrolysis of methionyl-lysyl-bradykinin was monitored by amino acid analysis by the procedure of Spackman et al. (1958). The enzyme samples were incubated with $280 \mu \mathrm{M}$ substrate in the above buffer, for 30 min at $37^{\circ} \mathrm{C}$. One enzyme unit is defined as the amount of enzyme hydrolysing $1.0 \mu \mathrm{mol}$ of substrate $/ \mathrm{min}$ under the described conditions.

\section{RESULTS AND DISCUSSION}

Rat liver homogenate contains several enzymes displaying arylamidase activity, the highest activity always being that towards methionine 2-naphthylamide (Mäkinen \& Raekallio, 1968; Freitas et al., 1981).
However, at least four distinct arylamidase activities could be separated after detergent solubilization and DEAE-cellulose chromatography (Freitas et al., 1981). It is now shown that two of these enzymes are active on splitting methionine 2-naphthylamide (Fig. 1a). A similar chromatographic pattern was obtained when the particulate preparations from microsomal fraction, light mitochondria and heavy mitochondria were fractionated (Figs. $1 b-1 d$ ).

The results also show that in rat liver homogenate and particles the methionine 2-naphthylamidase activity is associated with two distinct enzymes. A comparison between these two activities showed that only the enzyme from the first peak (Fig. 1) is a typical aminopeptidase, the second enzyme being active only upon amino acid 2-naphthylamides (Table 1). Other comparative studies also showed (Table 1) that the true aminopeptidase has a marked preference for the hydrolysis of $N$-terminal methionine from peptides and synthetic chromogenic substrates. These results confirm our previous finding (Freitas et al., 1981) suggesting the existence of these two distinct enzymes with methionine 2-naphthylamidase activity, one of them being a methionine aminopeptidase (MAP), which is defined as the one not retained on the DEAE-cellulose column.

Further purification of the detergent-solubilized MAP was obtained after sequential fractionation with $\left(\mathrm{NH}_{4}\right)_{2} \mathrm{SO}_{4} \quad(0.35-0.60$ saturation), DEAE-cellulose chromatography and gel filtration on a Bio-Gel A-0.5 m column. A high degree of instability of the fractionated enzyme was always observed, even at $-20^{\circ} \mathrm{C}$. The enzyme activity could, however, be preserved in the organelles if they were kept frozen $\left(-20^{\circ} \mathrm{C}\right)$, but not at $4^{\circ} \mathrm{C}$. No protection of the enzyme could be obtained with phosphatidylcholine, aminophospholipidsor 2-mercaptoethanol. The results suggest that on solubilization the enzyme loses a membrane stabilizing factor, probably as the result of conformational changes occurring during membrane solubilization and further purification. Thus purification beyond this step could not be performed. However, polyacrylamide-disc-gel electrophoresis of this purified preparation showed only one active band when unstained gels prepared in non-denaturating conditions were sliced, extracted with buffer and assayed with methionine 2-naphthylamide. Stained gels showed, in addition, the presence of two contaminant though enzymically inactive protein bands.

The purified MAP preparation was next incubated with haemoglobin nascent peptides having radioactive $\mathrm{N}$ terminal methionine, obtained from rabbit reticulocytes (see the Materials and methods section). It can be seen (Fig. 2) that the amount of $\left[{ }^{14} \mathrm{C}\right]$ methionyl-peptides present in the peptides from the control sample decreased, whereas in the MAP-treated sample the peak corresponding to free $\left[{ }^{14} \mathrm{C}\right]$ methionine increased proportionally. The time-course release of $\left[{ }^{35} \mathrm{~S}\right]$ methionine from ${ }^{[35}$ S]methionine-labelled peptides is shown in another series of experiments (Fig. 2 inset). These results clearly show that MAP is able to remove $N$-terminal methionine from the nascent peptides, thus confirming its typical aminopeptidase activity.

The properties of MAP clearly indicate its distinction from all other well-characterized arylaminopeptidases. It displays the unique property of being more active upon methionine 2-naphthylamide, whereas others markedly prefer alanine 2-naphthylamide (Freitas et al., 1979; 


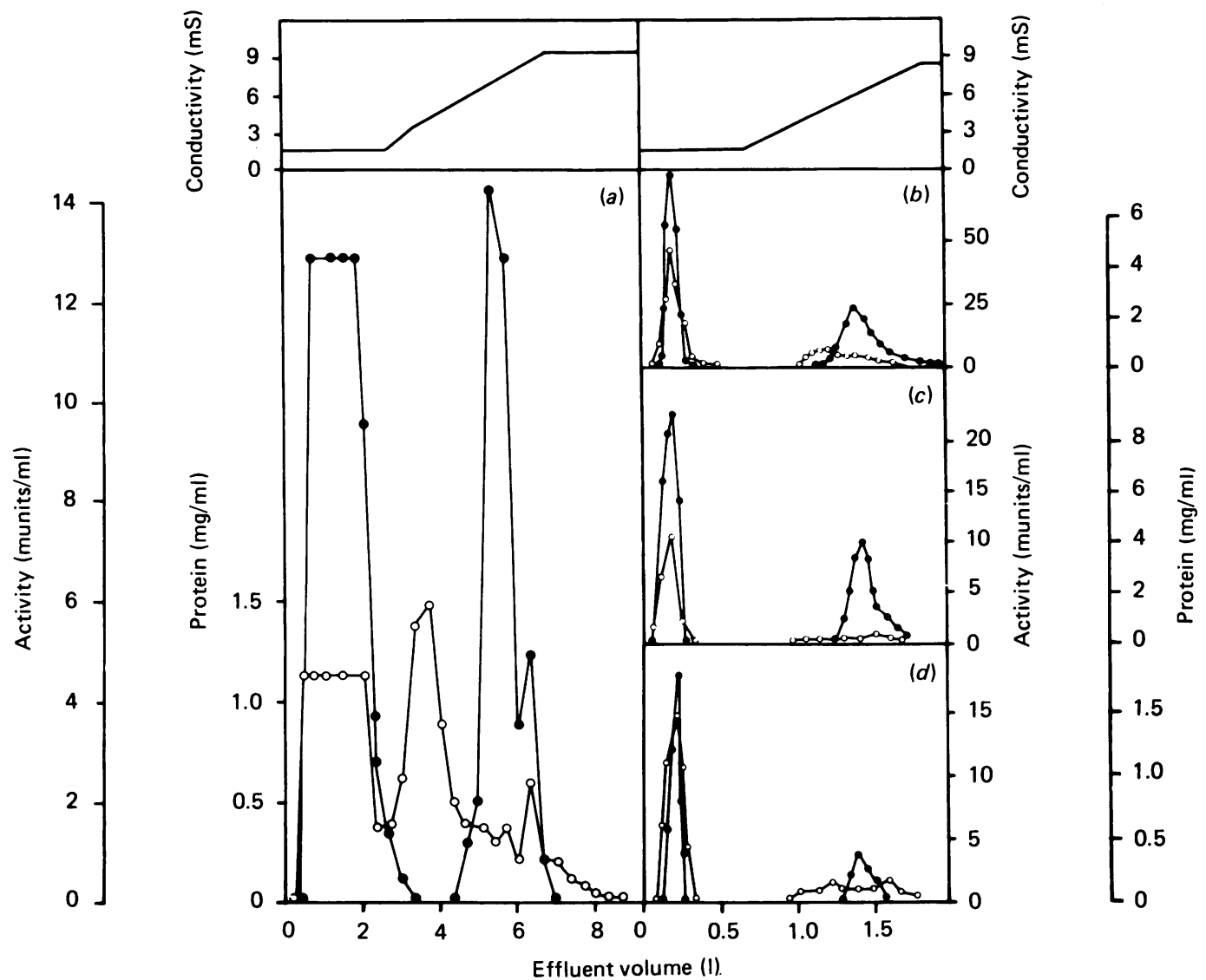

Fig. 1. DEAE-cellulose chromatographic fractionation of rat liver methionine 2-naphthylamidase activities

(a) Crude liver homogenate. The livers $(110 \mathrm{~g})$ from ten adult Wistar rats were homogenized as described (see the Materials and methods section). The homogenate or the liver organelles were treated with Triton X-100 at a 5:1 detergent/protein ratio. After centrifugation $\left(10000 \mathrm{~g}\right.$ for $30 \mathrm{~min}$ at $\left.4{ }^{\circ} \mathrm{C}\right)$ the supernatant was precipitated with $\left(\mathrm{NH}_{4}\right)_{2} \mathrm{SO}_{4}(0.35-0.60$ saturation $)$. The pellet was dissolved and dialysed against the column equilibrating buffer (see the Materials and methods section). The sample, $1.270 \mathrm{ml}$ containing $3.2 \mathrm{~g}$ of protein, was then applied to the column $(2.25 \mathrm{~cm} \times 26.2 \mathrm{~cm})$ of DEAE-cellulose at $4{ }^{\circ} \mathrm{C}$. After the column had been washed with the equilibrating buffer, adsorbed proteins were eluted in a 20-200 mM-phosphate gradient. Fractions $(17 \mathrm{ml})$ were collected at a flow rate of $130 \mathrm{ml} / \mathrm{h}$. $\bigcirc$, Protein; $\bigcirc$, methionine 2-naphthylamidase activity; phosphate gradient. $(b)-(d)$ Rat liver subcellular fractions: $(b)$ heavy mitochondria (622 mg of protein); (c) light mitochondria (441 mg of protein); (d) microsomal fraction (104 mg of protein). The chromatographic procedure was similar to that of (a) except for column sizes $(3.4 \mathrm{~cm} \times 11.0 \mathrm{~cm}$ each $)$. Fractions $(2.0 \mathrm{ml})$ were collected at a flow rate of $40 \mathrm{ml} / \mathrm{h}$ in each case.

Table 1. Specificity of the membrane-bound rat liver methionine 2-naphthylamidase activities on some 2-naphthylamides and peptides

Peaks 1 and 2 refer to the enzyme peaks in the DEAE-cellulose column chromatography (Fig. 1). Abbreviations: -Nap, 2-naphthylamide; N.D., not determined.

\begin{tabular}{lccc}
\hline & & \multicolumn{2}{c}{ Relative activity } \\
\cline { 3 - 4 } Substrate & Enzyme $\ldots$ & $\begin{array}{l}\text { Peak 1 } \\
\text { (MAP) }\end{array}$ & Peak 2 \\
\hline Met-Nap & & \\
Leu-Nap & 1.00 & 1.00 \\
Ala-Nap & 0.57 & 0.81 \\
Lys-Nap & 0.15 & 1.08 \\
Arg-Nap & 0.04 & 0.90 \\
Met-Ala-Ser & 0.07 & 1.10 \\
Met-Lys-bradykinin & 0.01 & N.D. \\
Lys-bradykinin & 2.31 & 0 \\
& & 0.01 & 0
\end{tabular}

Sidorowicz et al., 1981), arginine 2-naphthylamide (Hopsu et al., 1966; Freitas et al., 1979) or leucine 2-naphthylamide(Delange \& Smith, 1971). This particular feature of MAP has been shown to be responsible for its higher catalytic efficiency $\left(V_{\max } / K_{\mathrm{m}}\right)$ for hydrolysis of methionine 2-naphthylamide compared with other amino acid 2-naphthylamides (Freitas et al., 1985). Furthermore, we found that MAP, in contrast with other wellcharacterized aminopeptidases, is not inhibited by EDTA, puromycin or bestatin (Freitas et al., 1985). In addition, the lack of EDTA inhibition indicates that MAP is also distinct from all other known metalloaminopeptidases (Barrett, 1977). It is now shown that MAP displays preferential hydrolytic activity for the cleavage of $\mathrm{N}$-terminal methionine from oligopeptides such as methionyl-lysyl-bradykinin (Table 1) and haemoglobin nascent peptides (Fig. 2).

These properties of MAP may connect it with two other enzymes. The existence of two distinct aminopeptidases present in rabbit reticulocytes and able to hydrolyse off 


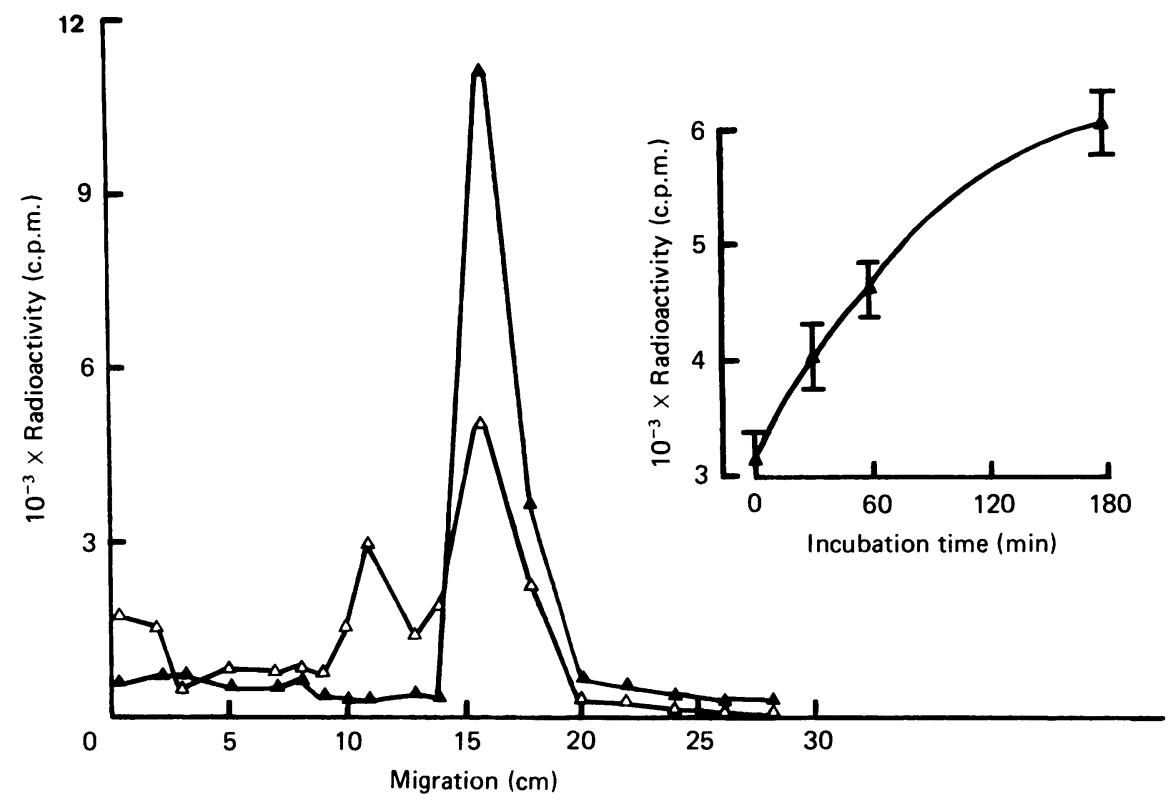

Fig. 2. Removal of $\mathbf{N}$-terminal methionine from rabbit haemoglobin nascent peptides by $\mathrm{MAP}$ : identification of released $\left[{ }^{14} \mathrm{C}\right] \mathrm{methionine}$

[ $\left.{ }^{14} \mathrm{C}\right]$ Methionine-labelled haemoglobin nascent peptides obtained as described in the Materials and methods section, and corresponding to 25000 c.p.m., were incubated for $12 \mathrm{~h}$ at $37^{\circ} \mathrm{C}$ in $500 \mu \mathrm{l}$ of $20 \mathrm{~mm}$-sodium phosphate, pH 7.0, containing $1 \mathrm{mM}-2$-mercaptoethanol in the absence (control, $\triangle$ ) or in the presence of $14 \mu \mathrm{g}$ of MAP ( $\Delta$ ). Samples from the incubation mixtures as well as non-radioactive methionine (added to the above buffer containing MAP) were applied to a Whatman 3MM chromatographic paper. After development (butanol/acetic acid/water, 4:1:1, by vol.) the chromatograms were dried; that corresponding to the control run (unlabelled methionine) was stained with ninhydrin, and the others were further cut into $1.5 \mathrm{~cm}$ pieces and the radioactivity of each piece was measured by liquid-scintillation counting. The inset shows a time-course curve for the hydrolysis of $N$-terminal methionine from haemoglobin nascent peptides. The enzyme $(27.6 \mu \mathrm{g})$ was incubated with ${ }^{35}$ S]methionine-labelled haemoblogin nascent peptides $(20000$ c.p.m.) in $500 \mu l$ of the above buffer. At different incubation times (30-180 min) $100 \mu l$ portions were removed and applied to the chromatographic paper, and handled as indicated for $(a)$. Results represent means \pm S.E.M. obtained in four experiments.

specifically either $N$-terminal methionine or $N$-terminal $N$-formylmethionine was reported by Yoshida \& Lin (1972). The authors suggested that these enzymes could be related to the removal of methionine and formylmethionine from nascent peptides. They also found a similar activity in the supernatant of a $10000 \mathrm{~g}$ rabbit liver homogenate as well as of other tissue homogenates. Suda et al. (1980) isolated from rat liver an arylamidase able to hydrolyse $N$-formylmethionine 2-naphthylamide that is distinct from a methionine 2-naphthylamidase activity also present in the liver homogenate. The latter enzyme seems to be similar to the enzymic activity found by Yoshida \& Lin (1972). Neither the former nor the latter authors further characterized these enzymes. It is, then, possible that MAP could be similar to the enzyme described by Yoshida \& Lin (1972), since both mitochondria and microsomal fraction could be expected to be present in their $10000 \mathrm{~g}$ supernatant. Additional work is required in order to characterize the relationship between MAP and any other related aminopeptidase.

This work was supported in part by grants from FINEP and CNPq (Brazil). C.T. was recipient of a CAPES/PICD (Brazil) fellowship.

\section{REFERENCES}

Barrett, A. J. (1972) Anal. Biochem. 47, 280-297

Barrett, A. J. (1977) in Proteinases in Mammalian Cells and Tissues (Barrett, A. J., ed.), pp. 1-53, Elsevier, Amsterdam
Berg, M. J. \& Marks, N. (1984) J. Neurosci. Res. 11, 313-321

Burch, J. P. H., Loeber, J. G., Verhoef, J., Wiegant, V. M., de Kloet, E. R. \& de Wield, D. (1980) Nature (London) 283, 96-97

Chambers, J. A. A. \& Rickwood, D. (1978) Centrifugation: A Practical Approach, pp. 33-46, Information Retrieval, London

Delange, R. J. \& Smith, E.-L. (1971) Enzymes 3rd Ed. 3, 8189

Freitas, J. O., Jr., Guimarães, J. A., Borges, D. R. \& Prado, J. L. (1979) Int. J. Biochem. 10, 81-89

Freitas, J. O., Jr., Termignoni, C., Borges, D. R., Sampaio, C. A. M., Prado, J. L. \& Guimarães, J. A. (1981) Int. J. Biochem. 13, 991-997

Freitas, J. O., Jr., Termignoni, C. \& Guimarães, J. A. (1985) Int. J. Biochem. 17, in the press

Guimarães, J. A., Borges, D. R., Prado, E. S. \& Prado, J. L. (1973) Biochem. Pharmacol. 22, 3157-3172

Hambrook, J. M., Morgan, B. A., Rance, M. J. \& Smith, C. F. C. (1976) Nature (London) 262, 782-783

Hersh, L. B., Smith, T. E. \& McKelvy, J. F. (1980) Nature (London) 286, 160-162

Hopsu, V. K., Mäkinen, K. K. \& Glenner, G. G. (1966) Arch. Biochem. Biophys. 114, 567-575

Mäkinen, P. L. \& Raekallio, J. (1968) Acta Chem. Scand. 22, 3111-3119

McDonald, J. K. \& Schwabe, C. (1977) in Proteinases in Mammalian Cells and Tissues (Barrett, A. J., ed.), pp. 311-391, Elsevier, Amsterdam

Olson, K. C., Fenno, J., Lin, N., Harkins, R. N., Snider, C., Kohr, W. H., Ross, M. J., Fodge, D., Prender, G. \& Stebbing, N. (1981) Nature (London) 293, 408-411 
Sidorowicz, W., Zownir, O. \& Behal, F. J. (1981) Clin. Chim. Acta 111, 69-79

Spackman, D. H., Stein, W. R. \& Moore, S. (1958) Anal. Chem. 30, 1190-1206

Suda, H., Yamamot, K., Aoyagi, T. \& Umezawa, H. (1980) Biochim. Biophys. Acta 616, 60-67

Received 23 July 1985/18 November 1985; accepted 2 December 1985
Tuppy, H. C. \& Nesvadba, H. (1957) Monatsh. Chem. 88, 977-988

Yoshida, A. \& Lin, M. (1972) J. Biol. Chem. 247, 952957

Yoshida, A., Watanabe, S. \& Morris, J. (1970) Proc. Natl. Acad. Sci. U.S.A. 67, 1600-1607 